\title{
Corrigendum: Antioxidant assessment of characterised essential oils from Calophyllum inophyllum Linn using 2,2-diphenyl-1- picrylhydrazyl and hydrogen peroxide methods
}

\begin{tabular}{|c|c|}
\hline \multicolumn{2}{|c|}{$\begin{array}{l}\text { Authors: } \\
\text { Emmanuel O. Ojah }^{1} \text { (D) } \\
\text { Dorcas O. Moronkola } \\
\text { Paul M. Osamudiamen }\end{array}$} \\
\hline \multicolumn{2}{|c|}{$\begin{array}{l}\text { Affiliations: } \\
{ }^{1} \text { Department of Chemistry, } \\
\text { University of Ibadan, Ibadan, } \\
\text { Nigeria }\end{array}$} \\
\hline \multicolumn{2}{|c|}{$\begin{array}{l}{ }^{2} \text { Marine Biodiversity Centre, } \\
\text { University of Aberdeen, } \\
\text { Aberdeen, United Kingdom }\end{array}$} \\
\hline \multicolumn{2}{|c|}{$\begin{array}{l}{ }^{3} \text { Department of Chemical } \\
\text { Sciences, Bells University of } \\
\text { Technology, Ota, Nigeria }\end{array}$} \\
\hline \multicolumn{2}{|c|}{$\begin{array}{l}\text { Corresponding author: } \\
\text { Emmanuel Ojah, } \\
\text { eojah7403@stu.ui.edu.ng }\end{array}$} \\
\hline \\
\hline \multicolumn{2}{|c|}{$\begin{array}{l}\text { How to cite this article: } \\
\text { Ojah, E.O., Moronkola, D.C } \\
\text { Osamudiamen, P.M., } 2021 \\
\text { 'Corrigendum: Antioxidant } \\
\text { assessment of characterise } \\
\text { essential oils from Calophy } \\
\text { inophyllum Linn using } \\
\text { 2,2-diphenyl-1- picrylhydra } \\
\text { and hydrogen peroxide } \\
\text { methods', Journal of Medi } \\
\text { Plants for Economic } \\
\text { Development 5(1), a138. } \\
\text { https://doi.org/10.4102/ } \\
\text { jomped.v5i1.138 }\end{array}$} \\
\hline \multicolumn{2}{|c|}{$\begin{array}{l}\text { Copyright: } \\
\text { (C) 2021. The Authors } \\
\text { Licensee: AOSIS. This } \\
\text { is licensed under the } \\
\text { Creative Commons } \\
\text { Attribution License. }\end{array}$} \\
\hline \multicolumn{2}{|l|}{ Read online: } \\
\hline 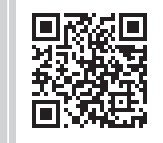 & $\begin{array}{l}\text { Scan this QR } \\
\text { code with your } \\
\text { smart phone or } \\
\text { mobile device } \\
\text { to read online. }\end{array}$ \\
\hline
\end{tabular}

In the version of the article initially published, Ojah, E.O., Moronkola, D.O. \& Osamudiamen, P.M., 2020, 'Antioxidant assessment of characterised essential oils from Calophyllum inophyllum Linn using 2,2-diphenyl-1- picrylhydrazyl and hydrogen peroxide methods', Journal of Medicinal Plants for Economic Development 4(1), a83. https://doi.org/10.4102/jomped.v4i1.83, a reference was omitted on pages $2,4,6,7$ and 9 . The text is now updated as follows:

The last paragraph in the Introduction section on page 2 should read:

\begin{abstract}
Calophyllum inophyllum Linn is the most abundant species in genus Calophyllum and is widespread in tropical areas, with a wide variety of uses ranging from traditional, medicinal and industrial applications (Dweck \& Meadowst 2002). The extracted oil from the fruit of C. inophyllum Linn is used as a remedy for sciatica, shingles, neuritis, rheumatism, ulcers and skin diseases, whilst the seed oil is reported to have medicinal and healing properties. The plant's dried leaves and its decoction are widely used in curing rheumatism, skin infections, cuts and sores (Uma et al. 2012). Its leaf and stem bark extracts have shown anti-hyperglycaemic and anti-hyperlipidaemic activities, whilst the leaf extract was identified to inhibit OS (Varsha et al. 2016). Its fruits are effectively utilised in the treatment of dermatitis (Yu et al. 2016). The broad spectrum of biological activities exhibited by $C$. inophyllum may be associated with the chemical composition of its different parts (Figures 1-3). Ojah et al., reported the chemical constituents and toxicity levels of ten essential oils from this plant. GC-MS analysis of volatile constitituents from the plant revealed that the plant is furnished with non-toxic volatile constituents with promising biological activities (Ojah et al. 2019). This article was therefore designed to evaluate the antioxidant properties of gas chromatography-mass spectrophotometry (GC-MS) characterised EOs from 10 parts of C. inophyllum Linn using the generally reliable 2,2-diphenyl-1-picrylhydrazyl (DPPH) and hydrogen peroxide models.
\end{abstract}

The first paragraph under the heading 'Essential oil composition of C. inophyllum Linn' in the Results and discussion section on page 4 should read:

The GC-MS characterisations of the leaf, leaf stalk, flower oil, pod, peel, stem wood, stem bark, root wood and root bark EOs extracted from C. inophyllum Linn showed a total of 102 compounds, which are mostly monoterpenes, sesquiterpenes and their oxygenated derivatives as shown in Table 2 (Ojah et al. 2019).

The footnote for Table 2a and Table $2 \mathrm{~b}$ on page 6 should read:

Source: Ojah, E.O., Moronkola D.O., Riccardo P., Nzekoue F.K., Loredana C., Cristiano G., Marcel J. \& Jioji N.T., 2019, 'Chemical Composition of ten Essential oils from Calophyllum inophyllum and their Toxicity against Artemia salina', European Journal of Pharmaceutical and Medical Research 6(12),185-194.

The third last paragraph under the heading 'Essential oil composition of C. inophyllum Linn' under the Results and discussion section on page 7 should read:

Stem bark oil contains nine compounds that make up $69.38 \%$ of it. This oil is rich in hexadecanal (46.80), E-anethole (6.12) and limonene (3.24). The oil is dominated by non-terpenes $(60.90 \%)$ and monoterpenes $(8.48 \%)$, whilst sesquiterpenes were absent. Root wood oil contains 51 compounds that make up $58.73 \%$ of it. This plant part is rich in non-terpenes $(45.80 \%)$ and sesquiterpenes $(12.83 \%)$, whilst monoterpenes were absent. This oil is rich in hexanedioic acid (9.86), E-nerolidol (5.83) and $\alpha$-bisabolol (4.36). The oil also contains methyl eugenol, a phenylpropanoid. Root bark oil has 24 compounds that make up $74.66 \%$ of it, which are mainly with monoterpenes (44.01), diterpenes (15.05) and non-terpenes (14.46). This oil is rich in cembrene-3Z (15.05), limonene (13.93) and hexadecanal (10.61) (Ojah et al. 2019). 
The last paragraph under the heading 'Essential oil composition of C. inophyllum Linn' under the Results and discussion section on page 7 should read:

The high content of $\gamma$-terpinene in leaf stalk (13.06\%), seed coat $(6.77 \%)$ and root bark $(7.75 \%)$ oils of C. inophyllum Linn is responsible for the anti-inflammatory and antioxidant effects, thus supporting the plant's anti-osteoarthritic activity. The presence of Terpinene in Hyptis species inhibited gastric lesions, reduced volume and acidity of the gastric juice and increased gastric wall mucus (Marcelo, Rafael \& Lucio 2015). Limonene, which is found in an appreciable amount in stem heartwood $(23.79 \%)$, stem bark (3.24\%) and root bark (13.93\%) EOs of C. inophyllum Linn, is known to have sedative and stimulative effects in Lippia alba (Vale et al. 2002; Viana, Vale \& Matos 2000). Consumption of diets containing fruits and vegetables rich in monoterpenes, such as limonene, is known to reduce the risk of developing cancer of the colon, mammary gland, liver, pancreas and lung. Limonene, which is known to possess high anticancer properties (Chistani et al. 2007; Marostica et al. 2009), is abundant in C. inophyllum Linn: leaf stalk (25.40\%), seed $(25.40 \%)$ and root bark $(13.93 \%)$ oils. The presence of phenylpropanoids, norisoprenoids and other non-ubiquitous compounds, such as $\beta$-alaskene, $\beta$-acoradiene and E-anethole, is a unique feature of oils from C. inophyllum Linn as shown in Table 2 (Ojah et al. 2019).

In the references list on page 8 , the following reference should be added:

Ojah, E.O., Moronkola D.O., Riccardo P., Nzekoue F.K., Loredana C., Cristiano G., Marcel J. \& Jioji N.T., 2019, 'Chemical Composition of ten Essential oils from Calophyllum inophyllum and their Toxicity against Artemia salina', European Journal of Pharmaceutical and Medical Research 6(12),185-194.

This correction does not alter the study's findings of significance or overall interpretation of the study's results. The authors apologise for any inconvenience caused. 


\section{Antioxidant assessment of characterised essential oils from Calophyllum inophyllum Linn using 2,2-diphenyl-1-picrylhydrazyl and hydrogen peroxide methods}

\begin{tabular}{|c|c|}
\hline \multicolumn{2}{|c|}{$\begin{array}{l}\text { Authors: } \\
\text { Emmanuel O. Ojah }{ }^{1} \text { (1) } \\
\text { Dorcas O. Moronkola } \\
\text { Paul M. Osamudiamen }\end{array}$} \\
\hline \multicolumn{2}{|c|}{$\begin{array}{l}\text { Affiliations: } \\
{ }^{1} \text { Department of Chemistry, } \\
\text { University of Ibadan, Ibadan, } \\
\text { Nigeria }\end{array}$} \\
\hline \multicolumn{2}{|c|}{$\begin{array}{l}{ }^{2} \text { Marine Biodiversity Centre, } \\
\text { University of Aberdeen, } \\
\text { Aberdeen, United Kingdom }\end{array}$} \\
\hline \multicolumn{2}{|c|}{$\begin{array}{l}{ }^{3} \text { Department of Chemical } \\
\text { Sciences, Bells University of } \\
\text { Technology, Ota, Nigeria }\end{array}$} \\
\hline \multicolumn{2}{|c|}{$\begin{array}{l}\text { Corresponding author: } \\
\text { Emmanuel Ojah, } \\
\text { eojah7403@stu.ui.edu.ng }\end{array}$} \\
\hline \multicolumn{2}{|c|}{$\begin{array}{l}\text { Dates: } \\
\text { Received: } 21 \text { Apr. } 2020 \\
\text { Accepted: } 10 \text { July } 2020 \\
\text { Published: } 08 \text { Sept. } 2020\end{array}$} \\
\hline \multicolumn{2}{|c|}{$\begin{array}{l}\text { How to cite this article: } \\
\text { Ojah, E.O., Moronkola, D.O. \& } \\
\text { Osamudiamen, P.M., 2020, } \\
\text { 'Antioxidant assessment of } \\
\text { characterised essential oils } \\
\text { from Calophyllum inophyllum } \\
\text { Linn using 2,2-diphenyl-1- } \\
\text { picrylhydrazyl and hydrogen } \\
\text { peroxide methods', Journal of } \\
\text { Medicinal Plants for } \\
\text { Economic Development 4(1), } \\
\text { a83. https://doi.org/10.4102/ } \\
\text { jomped.v4i1.83 }\end{array}$} \\
\hline \multicolumn{2}{|l|}{ Read online: } \\
\hline 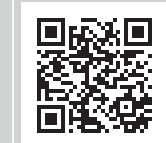 & $\begin{array}{l}\text { Scan this QR } \\
\text { code with your } \\
\text { smart phone or } \\
\text { mobile device } \\
\text { to read online. }\end{array}$ \\
\hline
\end{tabular}

Background: Oxidative stress is a multifactorial global health disorder that disrupts all levels of cell function. Therefore, therapeutic intervention using reliable, affordable and non-toxic natural sources is crucial.

Aim: The aim of this article was to determine the chemical constituents and antioxidant activity of 10 essential oils (EOs) from Calophyllum inophyllum Linn using 2,2-diphenyl-1picrylhydrazyl (DPPH) and hydrogen peroxide $\left(\mathrm{H}_{2} \mathrm{O}_{2}\right)$ methods.

Setting: Plant sample was collected at the Botanical Garden, University of Ibadan, Nigeria. Extractions and antioxidant assay were performed at the Organic Chemistry Research Laboratory, University of Ibadan, Nigeria. Gas chromatography-mass spectrophotometry (GC-MS) analysis was carried out at the School of Pharmacy, University of Camerino, Italy.

Methods: The chemical constituents were determined using GC-MS. The oils were extracted using an all-glass Clevenger-type apparatus and the antioxidant activity was determined using DPPH and hydrogen peroxide assays.

Results: A total of 102 compounds were identified in EOs from C. inophyllum Linn, which are mostly monoterpenes, sesquiterpenes and their oxygenated derivatives. The oils exhibited concentration-dependent activity with reference to standard synthetic antioxidants. Root wood had the highest antioxidant activity with the half maximal inhibitory concentration $\left(\mathrm{IC}_{50}\right)$ of $3.19 \mathrm{mg} / \mathrm{mL}$ compared to ascorbic acid $(2.84 \mathrm{mg} / \mathrm{mL})$ and butylated hydroxyl anisole (BHA) $(2.97 \mathrm{mg} / \mathrm{mL})$. In the $\mathrm{H}_{2} \mathrm{O}_{2}$ antioxidant assay, root wood had the highest antioxidant activity with $\mathrm{IC}_{50}$ of $2.78 \mathrm{mg} / \mathrm{mL}$ compared to ascorbic acid $(2.20 \mathrm{mg} / \mathrm{mL})$ and BHA $(2.92 \mathrm{mg} / \mathrm{mL})$.

Conclusion: The in vitro chemical compositional analysis of EOs from C. inophyllum Linn confirms the presence of compounds responsible for the antioxidant properties of the plant.

Keywords: Calophyllum inophyllum; essential oils; antioxidant; oxidative stress; hydrodistillation.

\section{Introduction}

Recently, researches on the antioxidant evaluation of volatile constituents from medicinal plants have increased geometrically as a result of gross increase in health disorders triggered by oxidative imbalance. This imbalance is caused by reactive oxygen species (ROS), which is because of the inability of antioxidants in the body to scavenge the effects of free radicals generated in the human system. Excess amount of ROS is deleterious because they can initiate biomolecular oxidative chain reactions (Bhaskara et al. 2015; Rattan 2006). When reactive radicals are generated in the body, the process disrupts all levels of cell function, resulting in oxidative stress (OS). Oxidative stress is associated with increased production of oxidising species or a significant decrease in the effectiveness of antioxidant defences. It can result in numerous diseases and disorders, such as ageing, cancers, rheumatoid arthritis and cardiovascular diseases (Saiket et al. 2010). Antioxidants are molecules that can safely react with free radicals and terminate the chain reaction before vital molecules are damaged (Ajiboye, Moronkola \& Adesomoju 2017). These free radicals and ROS may oxidise nucleic acids, proteins, lipids or deoxyribonucleic acid (DNA) and can trigger several degenerative

Copyright: ( 2020. The Authors. Licensee: AOSIS. This work is licensed under the Creative Commons Attribution License. 
diseases, such as atherosclerosis, stroke, diabetes and cancer, in humans (Ushio-Fukai \& Nakamura 2008). Antioxidants are believed to be prophylactic for the mentioned deleterious diseases. Human cells possess an inherent ROS scavenging mechanism, but this becomes inefficient and insufficient with age and under undue environmental stresses. Hence, dietary supplementation with synthetic antioxidants is necessary (Barros et al. 2011).

Plants have been utilised from time immemorial in the alternative and complementary treatment of several disease conditions, especially in developing economies like Nigeria where affordability and access to modern treatment is a major setback. Chemical constituents in medicinal plants possess several pharmacological potentials, which have been the focus of researches targeted at prospection of reliable, affordable and potent drugs (Mohammadhosseini et al. 2016; Nunes \& Miguel 2017). These constituents could be found in plant extracts or essential oils (EOs) with great activity useful for several therapeutic applications (Camilo et al. 2017; Ganesan \& Xu 2017; Pavunraj, Ramasubbu \& Baskar 2017).

Calophyllum inophyllum Linn is the most abundant species in genus Calophyllum and is widespread in tropical areas, with a wide variety of uses ranging from traditional, medicinal and industrial applications (Dweck \& Meadowst 2002). The extracted oil from the fruit of C. inophyllum Linn is used as a remedy for sciatica, shingles, neuritis, rheumatism, ulcers and skin diseases, whilst the seed oil is reported to have medicinal and healing properties. The plant's dried leaves and its decoction are widely used in curing rheumatism, skin infections, cuts and sores (Uma et al. 2012). Its leaf and stem bark extracts have shown anti-hyperglycaemic and antihyperlipidaemic activities, whilst the leaf extract was identified to inhibit OS (Varsha et al. 2016). Its fruits are effectively utilised in the treatment of dermatitis (Yu et al. 2016). The broad spectrum of biological activities exhibited by $C$. inophyllum may be associated with the chemical composition of its different parts (Figures 1-3). This article was therefore designed to evaluate the antioxidant properties of gas chromatography-mass spectrophotometry (GC-MS) characterised EOs from 10 parts of $C$. inophyllum Linn using the generally reliable 2,2-diphenyl-1-picrylhydrazyl (DPPH) and hydrogen peroxide models.

\section{Materials and methods Materials}

\section{Plant material}

Fresh samples of $C$. inophyllum Linn were collected from the Department of Botany, University of Ibadan, Ibadan, Oyo State, Nigeria. The samples were authenticated in the herbarium of the Department of Botany, University of Ibadan, Nigeria, where voucher samples were deposited with specimen voucher number UIH - 22659. The plant was sorted into 10 parts: leaf, stalk, flower, seed, pod, peel, stem wood, stem bark, root wood and root bark.

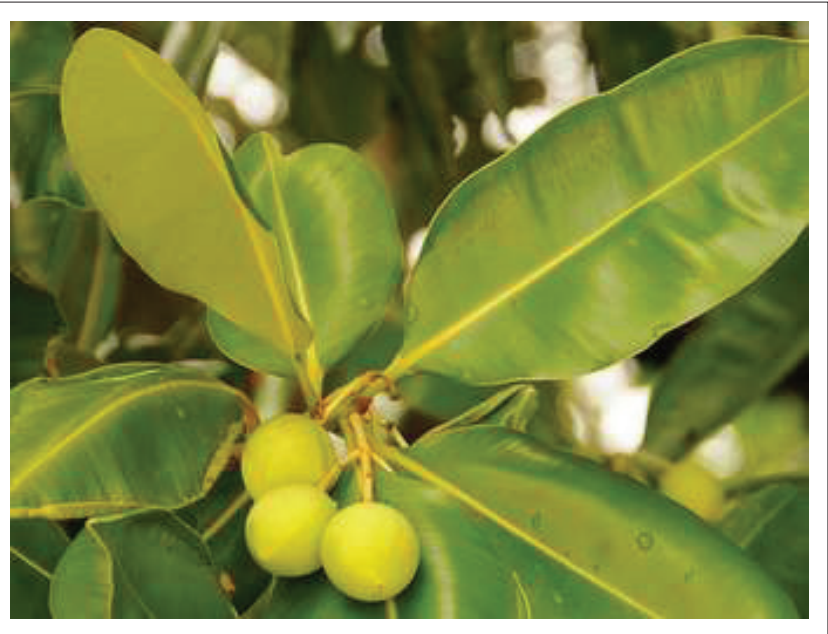

FIGURE 1: Fresh aerial part of Calophyllum inophyllum Linn.

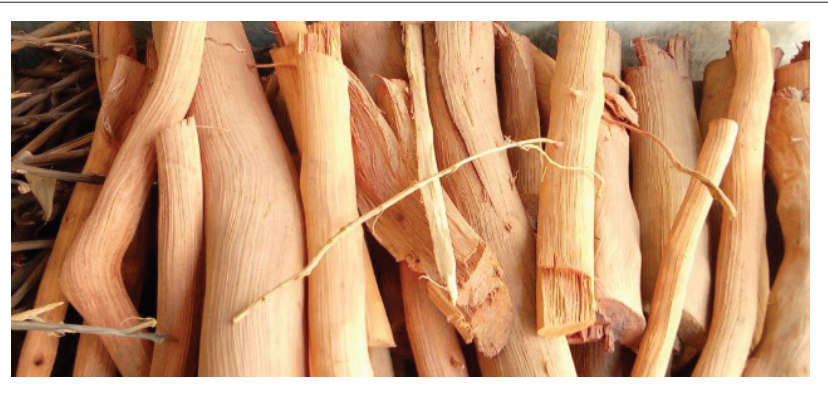

FIGURE 2: Root wood of Calophyllum inophyllum Linn.

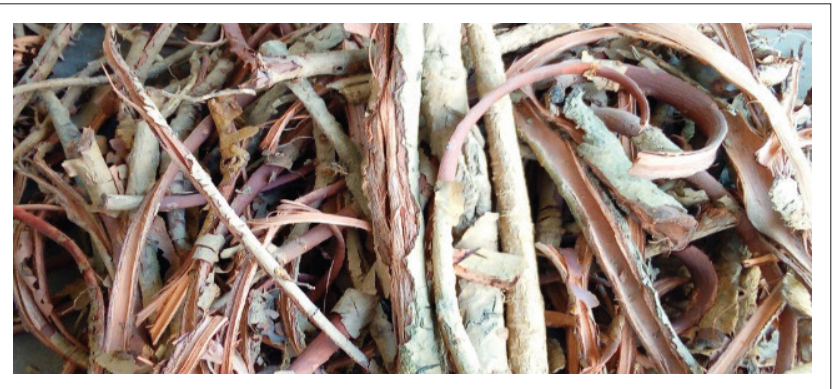

FIGURE 3: Root bark of Calophyllum inophyllum Linn.

\section{Solvents and chemicals}

Methanol (American Chemical Society [ACS] grade), hexane (ACS grade), butylated hydroxyl anisole (BHA), ascorbic acid, DPPH (95\%), hydrogen peroxide $\left(\mathrm{H}_{2} \mathrm{O}_{2}\right)$ distilled water, anhydrous sodium sulphate, sodium carbonate, deionized water (DI) and Whattman filter paper no. 3, 6-mm diameter were purchased from Sigma-Aldrich, Oakville, Ontario, Canada.

\section{Extraction of essential oil}

Each separated part (leaf, stalk, flower, seed, pod, peel, stem wood, stem bark, root wood and root bark) of C. inophyllum Linn was air-dried, pulverised and hydrodistilled for $3 \mathrm{~h}$ in an all-glass Clevenger-type apparatus designed according to British Pharmacopeia (BP) specifications (Figure 4). Essential oils were procured in $0.219 \%$ volume per weight $(\mathrm{v} / \mathrm{w})$ to $0.560 \%$ volume per weight $(\mathrm{v} / \mathrm{w})$ yields (Table 1$)$. 


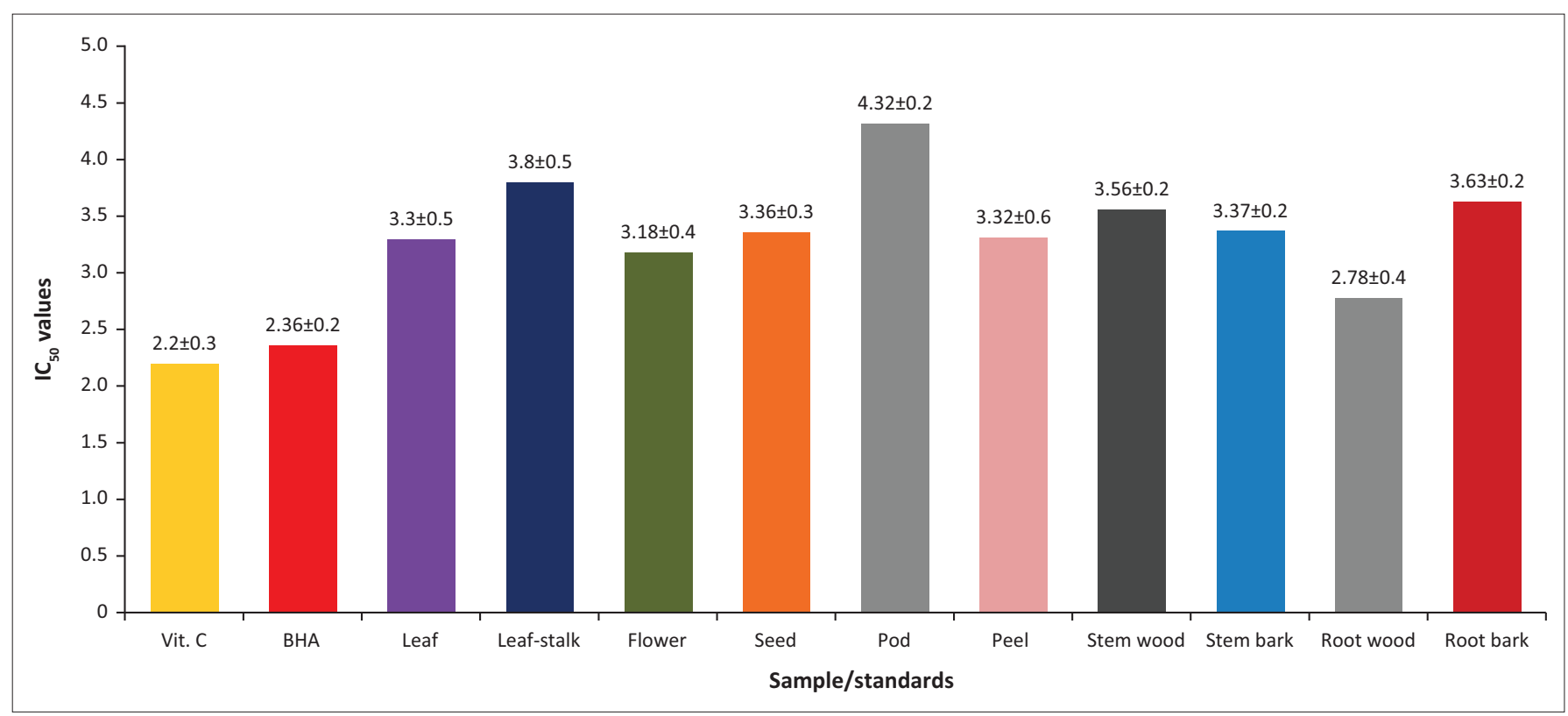

BHA, butylated hydroxyl anisole.

Note: All the results are mean \pm standard deviation (SD) where $n=3$. The half maximal inhibitory concentration $\left(\mathrm{IC}_{50}\right)$ was obtained in $\mathrm{mg} / \mathrm{mL}$ using non-linear regression analysis in Microsoft Excel. FIGURE 4: The half maximal inhibitory concentration values $(\mathrm{mg} / \mathrm{mL})$ for hydrogen peroxide inhibition of Calophyllum inophyllum.

TABLE 1: Percentage (\%) yield of 10 essential oils from Calophyllum inophyllum LINN.

\begin{tabular}{llcll}
\hline S/N & Plant parts & \% Yield & Colour & Odour \\
\hline 1. & Leaf & 0.333 & Pale yellow & Leafy \\
2. & Leaf stalk & 0.313 & Colourless & Herbal \\
3. & Flower & 0.288 & Colourless & Floral \\
4. & Seed & 0.305 & Cloudy white & Pleasant \\
5. & Pod & 0.506 & Pale red & Nut-like \\
6. & Peel & 0.560 & Pale yellow & Fruity \\
7. & Stem wood & 0.341 & Pale yellow & Woody \\
8. & Stem bark & 0.307 & Colourless & Nut-like \\
9. & Root wood & 0.219 & Pale red & Woody \\
10. & Root bark & 0.279 & Pale red & Nut-like \\
\hline
\end{tabular}

$\mathrm{S} / \mathrm{N}$, serial number.

The oils had a distinct characteristic smell. The EOs were refrigerated until the assay was carried out.

\section{Identification of essential oils by gas chromatography- mass spectrometry analyses}

Gas chromatography-mass spectrometry analyses were carried out by using an Agilent 7890B-5977B GC-MS (Santa Clara, California, United States) system operating in the EI mode at $70 \mathrm{eV}$, using an HP-5MS capillary column (5\% phenylmethyl polysiloxane, $30 \mathrm{~m}, 0.25 \mathrm{~mm}$ internal diameter (i.d.) and $0.1 \mu \mathrm{m}$ film thickness) (Jenning and Walter Scientific, Folsom, California, United States), which was programmed with the following conditions: $60^{\circ} \mathrm{C}$ for 4 minutes, then up to $4{ }^{\circ} \mathrm{C} /$ minutes to $160^{\circ} \mathrm{C}$, then $11^{\circ} \mathrm{C} /$ min up to $280{ }^{\circ} \mathrm{C}$, held for $15 \mathrm{~min}$, and finally $15{ }^{\circ} \mathrm{C} / \mathrm{min}$ up to $300{ }^{\circ} \mathrm{C}$. The carrier gas was helium at a flow rate of $1.2 \mathrm{~mL} / \mathrm{min}$, the injector temperature was $280{ }^{\circ} \mathrm{C}$ whilst the transfer line temperature was $300{ }^{\circ} \mathrm{C}$, the injection volume was $1 \mu \mathrm{L}$, the split ratio was $1: 100$, the run time was $57 \mathrm{~min}$ and the acquisition mass range was 29 atomic mass unit (amu) - $400 \mathrm{amu}$. Identification of the EO components was based on their retention indices (experimentally determined using homologous series of
C8-C30 alkanes) and by comparison of their mass spectral fragmentation patterns in computer matching against library linear retention index and mass spectra taken from Adams and NIST 17 [25] FFNSC2 and MAGGI libraries (Adams 2007; FFNSC2 2012; NIST 17 2017). Relative peak area percentages were obtained by peak area normalisation without using correction factors and were the mean of the three determinations with an relative standard deviation (RSD\%) in all cases below $10 \%$.

\section{Antioxidant activity}

2,2-diphenyl-1-picrylhydrazyl assay: The free radical scavenging activity of EOs from C. inophyllum Linn was determined using the stable DPPH radical (Ebrahimzadeh \& Bahramian 2009; Njenga \& Mugo 2020). The dark purple colour of DPPH is lost when it is reduced to non-radicals by antioxidants and decreases in its absorbance when monitored at a characteristic wavelength of $517 \mathrm{~nm}$. A $0.1 \mathrm{mM}$ concentration of DPPH was prepared by dissolving $3.94 \mathrm{mg}$ in $100 \mathrm{~mL}$ of methanol. An amount of $2 \mathrm{mg}$ of the EO was dissolved in $2 \mathrm{~mL}$ of methanol to prepare a $1.0 \mathrm{mg} / \mathrm{mL}$ concentration of the $\mathrm{EO}$, which was the stock solution. This stock solution was vortexed and serially diluted with methanol to obtain sample solutions of various concentrations, ranging from $1.0 \mathrm{mg} / \mathrm{mL}$ to $0.3125 \mathrm{mg} / \mathrm{mL}$. The six serially dilute concentrations $(1.0 \mathrm{mg} / \mathrm{mL}, 0.5 \mathrm{mg} / \mathrm{mL}, 0.25 \mathrm{mg} / \mathrm{mL}, 0.125 \mathrm{mg} / \mathrm{mL}$, $0.0625 \mathrm{mg} / \mathrm{mL}$ and $0.03125 \mathrm{mg} / \mathrm{mL}$ ) of EOs and standards were prepared in triplicates. Ascorbic acid (vitamin C) and BHA were used as standard positive controls. About $0.5 \mathrm{~mL}$ of each of these concentrations of the triplicates was added to $3 \mathrm{~mL}$ of pure methanol solution of DPPH (0.1 M). The absorbance of each sample concentration against methanol solution of DPPH blank was measured at $517 \mathrm{~nm}$ using an ultraviolet (UV) spectrophotometer. 
All readings were taken after $30 \mathrm{~min}$ of reaction time at room temperature. The decrease in absorbance of DPPH on the addition of test samples to the blank was used to calculate the percentage inhibition (I \%) using the following equation:

DPPH Inhibition $(\%)=\frac{\operatorname{Abs}(\text { Blank })-\operatorname{Abs}(\text { Essential oil })}{\operatorname{Abs}(\text { Blank })} * 100$

[Eqn 1]

where Abs (Blank) is the absorbance measurement of the blank and Abs $(E o)$ is the absorbance reading of EOs at $517 \mathrm{~nm}$.

Hydrogen peroxide scavenging activity: The ability of EOs from $C$. inophyllum Linn to scavenge hydrogen peroxide was determined using the hydrogen peroxide scavenging assay at different concentrations $(1.0 \mathrm{mg} / \mathrm{mL}$ - $0.03125 \mathrm{mg} / \mathrm{mL}$ ) (Kamalanathan et al. 2015; Njenga \& Mugo 2020; Serhat et al. 2012). A solution of hydrogen peroxide $(40 \mathrm{mM})$ was prepared in phosphate buffer at $\mathrm{pH}$ 7.4. The concentration of hydrogen peroxide was determined by absorption at $230 \mathrm{~nm}$ using a UVD. Essential oils and standards in distilled water were added to a hydrogen peroxide solution $(0.6 \mathrm{~mL}, 40 \mathrm{mM})$. The absorbance of hydrogen peroxide was determined after 30 min against a blank solution containing phosphate buffer without hydrogen peroxide. The absorbance value of the reaction mixture was recorded at $230 \mathrm{~nm}$ using ascorbic acid (vitamin C) and BHA as standard. The percentage of hydrogen peroxide scavenged by the EOs and standards was calculated as follows:

Hydrogen Peroxide inhibition (\%)

$$
=\frac{\operatorname{Abs}(\text { control })-\operatorname{Abs}(E O)}{\operatorname{Abs}(\text { control })} * 100
$$

where Abs (Blank) is the absorbance measurement of the blank and Abs (Eo) is the absorbance of EOs at $230 \mathrm{~nm}$.

\section{Statistical analysis}

The experiments were conducted three times, all determinations were performed in triplicates $(n=3)$ and the results were expressed as mean \pm standard deviation (SD). Statistical analysis was performed by non-linear regression analysis on Microsoft Excel. The half maximal inhibitory concentration $\left(\mathrm{IC}_{50}\right)$ values of 10 parts of C. inophyllum Linn were determined using non-linear regression analysis on Microsoft Excel in comparison with standards.

\section{Ethical consideration}

This article followed all ethical standards for a research without direct contact with human or animal subjects.

\section{Results and discussion Percentage yield of essential oils from C. inophyllum Linn}

Essential oils obtained from C. inophyllum Linn gave characteristic odours (herbal, floral and woody). The oils were procured in $0.219 \%$ to $0.506 \%$ yields (Table 1 ), with the highest yield from fruit pulp, which gave $0.560 \%$, and the lowest yield $(0.219 \%)$ from the root, which may be because of its high fibre content.

\section{Essential oil composition of $\boldsymbol{C}$. inophyllum Linn}

The GC-MS characterisations of the leaf, leaf stalk, flower oil, pod, peel, stem wood, stem bark, root wood and root bark EOs extracted from C. inophyllum Linn showed a total of 102 compounds, which are mostly monoterpenes, sesquiterpenes and their oxygenated derivatives as shown in Table 2.

A total of 71 compounds were characterised in leaf oil, which corresponded to $54.94 \%$ of the identified peaks. This oil consists mainly of sesquiterpenes $(22.18 \%)$ and nonterpenes $(27.89 \%)$. The predominant compounds in leaf oil are cis-cadina- $1(6)$, 4-diene $(6.50 \%)$, hexadecanal $(6.16 \%)$ and cis-calamenene (5.41). The oils contain non-ubiquitous norisoprenoids, such as $\alpha$-cyclocitral, $\beta$-cyclocitral and $\beta$-ionone. Leaf stalk essential oil gave 22 compounds, which constitute about $79.55 \%$ of it and are dominated by monoterpenes $(75.62 \%)$. The leaf stalk oil is a rich source of monoterpenes, such as limonene (23.79), $\gamma$-terpinene (13.06) and $p$-cymene (9.28). The presence of non-ubiquitous phenylpropanoids, such as methyl chavicol and methyl eugenol, may be responsible for the diverse bioactivities expressed by the leaf stalk. Flower oil had 25 identified compounds, which make up $51.24 \%$ of it. Over $50 \%$ of the oils are sesquiterpenes $(32.87 \%)$. The presence of characteristic chemical constituents, such as cis-cadina-1(6), 4-diene (15.42), $\beta$-alaskene (9.63) and $\gamma$-bisabolene (7.20), may be responsible for the impact notes of the plant. A sum of 25 compounds was identified in the cloudy white seed oil, which makes up about $89.39 \%$ of it. The compound is predominant in compounds such as limonene (25.40), $\gamma$-terpinene (14.00) and $p$-cymene (10.03). About 83.81\% of identified oils are classified as monoterpenes. Phenylpropanoids such as methyl chavicol were also present. Pod oil is made up of 69 compounds which constitute $73.80 \%$ of it. The pod is a rich source of non-terpenes (48.82) and monoterpenes (24.98). Limonene (16.85), $\quad \gamma$-terpinene (9.82) and p-cymene (6.70) are predominant in this part of the plant. 15 compounds were characterised in peel oil $(46.10 \%)$, which is a good source of cis-cadina-1(6), 4-diene (15.6\%), $\beta$-alaskene $(8.4 \%)$ and $\beta$-acoradiene. This oil is exclusively rich in sesquiterpenes $(45.80 \%)$. Fifty-five compounds were characterised in stem wood oil, which make up $59.40 \%$ of it. Predominant compounds in the stem wood oil include hexadecanal (6.87\%), E-nerolidol (5.86\%) and 1,8-cineole (5.63). This oil is rich in monoterpenes (22.96) and non-terpenes (28.11). 
TABLE 2a: Chemical constitution of 10 essential oils from Calophyllum inophyllum Linn.

\begin{tabular}{|c|c|c|c|c|c|c|c|c|c|c|c|c|c|}
\hline$S / N$. & RI & Compound & Class & Leaf & $\begin{array}{l}\text { Leaf } \\
\text { stalk }\end{array}$ & Flower & Seed & Pod & Peel & $\begin{array}{l}\text { Stem } \\
\text { wood }\end{array}$ & $\begin{array}{l}\text { Stem } \\
\text { bark }\end{array}$ & $\begin{array}{l}\text { Root } \\
\text { wood }\end{array}$ & $\begin{array}{l}\text { Root } \\
\text { bark }\end{array}$ \\
\hline 1. & 784 & 3-Hexanone & Alkanone & 0.13 & 0.05 & - & - & 4.76 & - & 0.14 & 1.72 & 0.17 & 0.07 \\
\hline 2. & 789 & 2-Hexanone & Alkanone & 0.50 & 0.07 & - & - & 3.21 & - & 1.00 & 1.85 & 0.82 & 0.12 \\
\hline 3. & 793 & 3-Hexanol & Alkanol & 0.09 & - & - & - & 3.16 & - & 0.12 & - & 0.11 & - \\
\hline 4. & 800 & Hexanal & Alkanal & 0.92 & 0.42 & 0.06 & 0.67 & 3.82 & - & 0.84 & - & 1.24 & 0.16 \\
\hline 5. & 844 & (E)-2-Hexenal & Alkanal & 1.05 & - & - & - & - & - & 0.06 & - & 0.10 & - \\
\hline 6. & 846 & 3-Hexen-1-ol & Alkanol & 0.23 & - & - & - & - & - & - & - & - & - \\
\hline 7. & 857 & (E)-2-Hexen-1-ol, & Alkanol & 0.99 & - & - & - & - & - & - & - & - & - \\
\hline 8. & 859 & $\mathrm{n}$-Hexanol & Alkanol & 3.33 & - & - & - & - & - & 0.14 & - & 0.09 & - \\
\hline 9. & 923 & Acetonyl acetone & Alkanone & 0.34 & - & - & - & - & - & 2.71 & - & 0.71 & - \\
\hline 10. & 926 & $\alpha$-Thujene & Monoterpene & - & 1.96 & - & 2.34 & - & - & 0.35 & - & - & 1.09 \\
\hline 11. & 932 & $\alpha$-Pinene & Monoterpene & 0.21 & 7.88 & 0.07 & 9.39 & - & - & 1.28 & - & 0.02 & 4.44 \\
\hline 12. & 945 & Acetoxyhexane & Ether & - & - & - & - & 4.80 & - & - & - & - & - \\
\hline 13. & 947 & Camphene & Monoterpene & - & 0.62 & - & 0.70 & - & - & - & - & - & 0.39 \\
\hline 15. & 969 & Sabinene & Monoterpene & - & 0.72 & - & 0.93 & - & - & - & - & - & - \\
\hline 16. & 975 & $\beta$-Pinene & Monoterpene & 0.11 & 4.41 & - & 5.13 & - & - & 0.73 & - & - & 2.54 \\
\hline 17. & 978 & 1-Octen-3-ol & Alkanol & 0.04 & - & - & - & - & - & 0.54 & - & 0.25 & - \\
\hline 18. & 987 & 6-methyl-5-Hepten-2-one, & Alkanone & 0.10 & - & - & - & - & - & 0.11 & - & 0.17 & - \\
\hline 19. & 991 & Myrcene & Monoterpene & 0.30 & 2.81 & - & 3.21 & - & - & 1.19 & - & - & 1.67 \\
\hline 20. & 1002 & trans-2-(2-Pentenyl)furan & Aromatic & 0.05 & - & - & - & - & - & - & - & - & - \\
\hline 21. & 1004 & $\alpha$-Phellandrene & Monoterpene & - & 0.27 & - & 0.32 & - & - & 0.26 & - & - & - \\
\hline 22. & 1010 & $\delta$-3-Carene & Monoterpene & 0.08 & 0.36 & - & 0.41 & - & - & 0.13 & - & 0.21 & - \\
\hline 23. & 1016 & $\alpha$-Terpinene & Monoterpene & 0.09 & 2.40 & - & 2.54 & - & - & 0.39 & - & - & 1.41 \\
\hline 24. & 1024 & p-Cymene & Monoterpene & 0.34 & 9.28 & 0.06 & 10.03 & 8.50 & - & 1.42 & 2.29 & - & 5.39 \\
\hline 25. & 1028 & Limonene & Monoterpene & 0.75 & 23.79 & 0.18 & 25.4 & 9.71 & - & 3.47 & 3.24 & - & 13.93 \\
\hline 26. & 1030 & 1,8-Cineole & Oxygenated MT & 0.30 & 5.33 & - & 5.69 & - & - & 5.63 & - & 0.39 & 3.54 \\
\hline 27. & 1034 & 2,2,6-trimethyl Cyclohexanone, & Alkanone & 0.05 & - & - & - & - & - & - & - & - & - \\
\hline 28. & 1039 & $\beta$-Ocimene & Monoterpene & - & 0.56 & - & 0.65 & - & - & 0.11 & - & - & 0.36 \\
\hline 29. & 1043 & Benzeneacetaldehyde & Aldehyde & 0.08 & - & - & - & - & - & - & - & - & - \\
\hline 32. & 1065 & Acetophenone & Alkanone & 0.61 & - & - & - & - & - & 0.43 & - & 0.21 & - \\
\hline 33. & 1071 & 1-Octanol & Alkanol & - & - & - & - & - & - & - & - & 0.31 & - \\
\hline 34. & 1087 & Terpinolene & Monoterpene & - & 0.70 & - & 0.84 & - & - & - & - & - & 0.53 \\
\hline 35. & 1100 & Linalool & Oxygenated MT & 0.12 & 0.63 & - & 0.62 & - & - & 2.62 & - & 1.96 & 0.46 \\
\hline 36. & 1105 & Nonanal & Alkanal & 0.31 & - & - & - & - & - & - & - & 1.79 & - \\
\hline 37. & 1116 & $\alpha$-Cyclocitral & Norisoprenoid & 0.04 & - & - & - & - & - & - & - & - & - \\
\hline 38. & 1134 & 2,2,6-trimethyl-cyclohexanone & Alkanone & - & - & - & - & - & - & 0.03 & - & 0.02 & - \\
\hline 39. & 1143 & Camphor & Oxygenated MT & - & - & - & 0.29 & - & - & 0.07 & - & - & - \\
\hline 40. & 1160 & (E)-2-Nonenal & Alkanal & 0.08 & - & - & - & - & - & 0.33 & - & 0.69 & - \\
\hline 41. & 1176 & Terpinen-4-ol & Oxygenated MT & - & - & - & - & - & - & 1.34 & - & 0.24 & - \\
\hline 42. & 1189 & $\alpha$-Terpineol & Oxygenated MT & - & - & - & - & - & - & 1.48 & - & 1.30 & - \\
\hline 43. & 1193 & Methyl salicylate & Aromatic & 0.08 & - & - & - & - & - & - & - & - & - \\
\hline 44. & 1195 & Myrtenol & Alkanol & - & - & - & - & - & - & - & - & 0.64 & - \\
\hline 45. & 1197 & Methyl chavicol & Phenylpropanoid & - & 0.59 & - & 0.73 & - & - & 0.09 & - & - & - \\
\hline 46. & 1198 & Safranal & Alkanal & 0.10 & - & - & - & - & - & - & - & - & 0.06 \\
\hline 47. & 1206 & Decanal & Alkanal & 0.09 & - & - & - & - & - & 0.46 & - & 0.73 & - \\
\hline 48. & 1220 & $\beta$-Cyclocitral & Norisoprenoid & 0.26 & - & - & - & - & - & - & - & - & - \\
\hline 49. & 1238 & Ascaridole & Oxygenated MT & - & - & - & - & - & - & 0.08 & - & - & - \\
\hline 50. & 1258 & Edulan II & Ether & 1.05 & - & - & - & - & - & 1.07 & - & 0.99 & - \\
\hline 51. & 1262 & 2-Decenal & Alkanal & 0.11 & - & - & - & - & - & 0.09 & - & 0.08 & - \\
\hline 52. & 1271 & $\alpha$-Citral & Alkanal & 0.04 & - & - & - & - & - & 0.12 & - & 0.14 & - \\
\hline 53. & 1285 & E Anethole & Ether & 0.13 & 2.80 & - & 3.66 & 25.45 & - & 0.87 & 6.12 & - & 2.04 \\
\hline 54. & 1293 & (E,Z)-2,4-Decadienal & Alkanal & - & - & - & - & - & - & - & - & 0.55 & - \\
\hline 55. & 1301 & Carvacrol & Oxygenated MT & - & - & - & 0.42 & - & - & 0.12 & - & - & - \\
\hline 56. & 1314 & Edulan I & Ether & 1.69 & - & - & - & - & - & - & - & - & - \\
\hline 57. & 1316 & (E,E)-2,4-Decadienal & Alkanal & - & - & - & - & - & - & - & - & 1.34 & - \\
\hline 58. & 1350 & $\alpha$-Cubebene & Sesquiterpene & - & - & 0.07 & - & - & - & - & - & - & - \\
\hline 59. & 1352 & 1,2-dihydro-1,1,6-trimethyl naphthalene & Aromatic & 0.14 & - & - & - & - & - & - & - & - & - \\
\hline
\end{tabular}


TABLE 2a(Continues...): Chemical constitution of 10 essential oils from Calophyllum inophyllum Linn.

\begin{tabular}{|c|c|c|c|c|c|c|c|c|c|c|c|c|c|}
\hline$S / N$. & RI & Compound & Class & Leaf & $\begin{array}{l}\text { Leaf } \\
\text { stalk }\end{array}$ & Flower & Seed & Pod & Peel & $\begin{array}{l}\text { Stem } \\
\text { wood }\end{array}$ & $\begin{array}{l}\text { Stem } \\
\text { bark }\end{array}$ & $\begin{array}{l}\text { Root } \\
\text { wood }\end{array}$ & $\begin{array}{l}\text { Root } \\
\text { bark }\end{array}$ \\
\hline 61. & 1367 & Cyclosativene & Sesquiterpene & 0.04 & - & - & - & - & - & - & - & - & - \\
\hline 62. & 1376 & Copaene & Sesquiterpene & 0.17 & - & 0.31 & - & - & 0.40 & 0.10 & - & 0.15 & - \\
\hline 63. & 1382 & (3Z)-3-Hexenyl hexanoate & Ester & 0.05 & - & - & - & - & - & - & - & - & - \\
\hline 64. & 1384 & $\beta$-Bourbonene & Sesquiterpene & 0.06 & - & 0.27 & - & - & - & - & - & - & - \\
\hline 65. & 1387 & n-Hexyl hexanoate & Ester & 0.77 & - & - & - & - & - & - & - & - & - \\
\hline 66. & 1391 & 7-epi-Sesquithujene & Sesquiterpene & 0.47 & - & 0.58 & - & - & 0.40 & - & - & - & - \\
\hline 67. & 1399 & Cyperene & Sesquiterpene & - & - & - & - & - & - & - & - & - & 1.14 \\
\hline 68. & 1400 & Tetradecane & Alkane & 0.10 & - & - & - & - & - & - & - & 4.19 & - \\
\hline 69. & 1405 & Methyl eugenol & phenylpropanoid & 0.03 & - & - & - & - & - & 0.05 & - & 0.10 & - \\
\hline 70. & 1413 & $\beta$-Cedrene & Sesquiterpene & 0.21 & - & 0.69 & - & - & 0.80 & - & - & - & - \\
\hline 71. & 1424 & $\beta$-Copaene & Sesquiterpene & - & - & - & - & - & 0.20 & - & - & - & - \\
\hline 72. & 1428 & $\alpha$-Ionone & Ester & 0.44 & - & - & - & - & - & - & - & - & - \\
\hline 73. & 1454 & 6,10-dimethyl 5,9-Undecadien-2-one & Alkanone & 0.89 & - & 0.09 & - & - & - & 0.39 & - & 0.97 & - \\
\hline 74. & 1458 & $\beta$-Farnesene & Sesquiterpene & 0.15 & - & - & - & - & 0.3 & - & - & - & - \\
\hline 75. & 1463 & Cis-Cadina 1,6 4 diene & Sesquiterpene & 6.50 & - & 15.42 & 0.37 & - & 15.60 & 0.45 & - & 0.84 & - \\
\hline 76. & 1467 & $\beta$-Acoradiene & Sesquiterpene & 2.54 & - & 5.72 & 0.15 & - & 5.60 & 0.25 & - & - & - \\
\hline 77. & 1477 & $\gamma$-Muurolene & Sesquiterpene & 0.34 & - & 0.22 & - & - & 0.70 & 0.15 & - & 1.11 & - \\
\hline 78. & 1481 & Germacrene & Sesquiterpene & 0.20 & - & 3.74 & - & - & 1.30 & - & - & - & - \\
\hline 79. & 1486 & (E)- $\beta$-lonone & norisoprenoid & 1.94 & - & - & - & - & - & 0.07 & - & 1.31 & - \\
\hline 80. & 1496 & $\beta$-Alaskene & Sesquiterpene & 2.73 & - & 9.63 & - & - & 8.40 & 0.44 & - & 1.56 & - \\
\hline 81. & 1509 & $\beta$-Bisabolene & Sesquiterpene & 0.16 & - & 0.28 & - & - & - & - & - & - & - \\
\hline 82. & 1516 & $\gamma$-Bisabolene & Sesquiterpene & - & - & 7.20 & - & - & 4.70 & - & - & - & - \\
\hline 83. & 1517 & (Z)- $\gamma$-Bisabolene & Sesquiterpene & 2.00 & - & - & - & - & - & - & - & 1.21 & - \\
\hline 84. & 1524 & $\delta$-Cadinene & Sesquiterpene & 1.20 & - & 0.86 & - & - & 2.00 & 0.27 & - & 0.82 & - \\
\hline 85. & 1534 & Cis-Calamenene & Sesquiterpene & 5.41 & - & 1.88 & - & - & 5.70 & 0.65 & - & 5.83 & - \\
\hline 86. & 1565 & E-Nerolidol & Sesquiterpene & - & - & - & - & - & - & 5.86 & - & - & - \\
\hline 87. & 1580 & $\begin{array}{l}\text { (3E,7E)-4,8,12-Trimethyltrideca-1,3,7, } \\
\text { 11-tetraene }\end{array}$ & Alkane & 0.20 & - & - & - & - & - & - & - & 0.92 & - \\
\hline 88. & 1660 & Neointermedeol & Alcohol & - & - & - & - & - & - & - & - & 1.48 & - \\
\hline 89. & 1682 & (Z)-3-Heptadecene, & Alkane & 0.77 & - & - & - & - & - & - & - & - & - \\
\hline 90. & 1689 & $\alpha$-Bisabolol & Alcohol & 0.28 & - & 0.50 & - & - & - & - & - & 4.36 & - \\
\hline 91. & 1818 & Hexadecanal & Alkanal & 6.16 & - & 2.54 & - & 3.62 & - & 6.87 & 46.80 & - & 10.61 \\
\hline 92. & 1848 & Hexahydrofarnesyl acetone & Polyacetylene & 0.77 & - & - & - & - & - & 0.18 & - & 0.72 & - \\
\hline 93. & 1973 & Cembrene A $3 Z$ & Diterpene & - & - & - & - & - & - & - & - & - & 15.05 \\
\hline 94. & 1881 & 1-Hexadecanol & Alkanol & 1.53 & - & 0.11 & - & - & - & 5.40 & 4.41 & 3.04 & - \\
\hline 95. & 1922 & Farnesyl acetone & Alkanone & 0.63 & - & - & - & - & - & - & - & 1.12 & - \\
\hline 96. & 1974 & n-Hexadecanoic acid & Alkanoic acid & - & - & - & - & - & - & - & - & 9.86 & - \\
\hline 97. & 1997 & 9-Octadecenal & Alkanal & 1.35 & - & 0.19 & - & - & - & 2.95 & - & 0.67 & - \\
\hline 98. & 2085 & n-Octadecanol & Alkanol & - & - & - & - & - & - & - & - & - & 0.90 \\
\hline 99. & 2086 & 2-Octadecen-1-ol & Alkanol & 1.20 & - & 0.47 & - & - & - & 2.74 & - & 0.86 & - \\
\hline 100. & 2496 & Pentacosane & Alkane & - & - & - & - & - & - & - & - & 1.08 & - \\
\hline 101. & 2599 & Hexacosane & Alkane & - & - & - & - & - & - & 0.24 & - & 0.67 & - \\
\hline 102. & 2900 & Nonacosane & Alkane & - & - & - & - & - & - & 0.23 & - & 0.32 & - \\
\hline
\end{tabular}

MT, monoterpenes.

TABLE 2b: Chemical constitution of 10 essential oils from Calophyllum inophyllum Linn.

\begin{tabular}{|c|c|c|c|c|c|c|c|c|c|c|}
\hline Compound & Leaf & Leaf stalk & Flower & Seed & Pod & Peel & Stem wood & Stem bark & Root wood & Root bark \\
\hline Total & 54.94 & 79.55 & 51.24 & 89.39 & 73.80 & 46.10 & 59.40 & 69.38 & 58.73 & 74.66 \\
\hline No. of compounds & 71 & 22 & 25 & 25 & 69 & 15 & 55 & 09 & 51 & 24 \\
\hline Monoterpenes & 2.86 & 75.62 & 0.41 & 83.81 & 24.98 & - & 22.96 & 8.48 & - & 44.01 \\
\hline Sesquiterpenes & 22.18 & - & 32.87 & 0.52 & - & 45.80 & 8.24 & - & 12.83 & 1.14 \\
\hline Diterpenes & - & - & - & - & - & - & - & - & - & 15.05 \\
\hline Norisoprenoids & 1.98 & - & - & - & - & - & - & - & - & - \\
\hline Non-terpenes & 27.89 & 3.34 & 17.96 & 4.33 & 48.82 & 0.30 & 28.11 & 60.90 & 45.80 & 14.46 \\
\hline
\end{tabular}

Stem bark oil contains nine compounds that make up $69.38 \%$ of it. This oil is rich in hexadecanal (46.80), E-anethole (6.12) and limonene (3.24). The oil is dominated by nonterpenes $(60.90 \%)$ and monoterpenes $(8.48 \%)$, whilst sesquiterpenes were absent. Root wood oil contains 51 compounds that make up $58.73 \%$ of it. This plant part is rich in non-terpenes $(45.80 \%)$ and sesquiterpenes $(12.83 \%)$, whilst monoterpenes were absent. This oil is 
rich in hexanedioic acid (9.86), E-nerolidol (5.83) and $\alpha$-bisabolol (4.36). The oil also contains methyl eugenol, a phenylpropanoid. Root bark oil has 24 compounds that make up $74.66 \%$ of it, which are mainly with monoterpenes (44.01), diterpenes (15.05) and non-terpenes (14.46). This oil is rich in cembrene-3Z (15.05), limonene (13.93) and hexadecanal (10.61).

Generally, the essential oils are dominated by cymene, terpinene and limonene. Cymene, which is present in a relatively large percentage in eight of the oils from C. inophyllum Linn, has been reported as a good antioxidant, anti-inflammatory, anti-nociceptive, anxiolytic, anticancer and antimicrobial agent (DeOliveira et al. 2015), which corroborates the ethno-medicinal applications of the plant. In a recent in vivo investigation on an experimental animal model, p-cymene was found to increase the activity of antioxidant enzymes, thereby reducing the OS; the high antimicrobial potential of Carum copticum EO was also attributed to the abundance of cymene and terpinene (Hassan et al. 2016).

The high content of $\gamma$-terpinene in leaf stalk (13.06\%), seed coat $(6.77 \%)$ and root bark (7.75\%) oils of C. inophyllum Linn is responsible for the anti-inflammatory and antioxidant effects, thus supporting the plant's anti-osteoarthritic activity. The presence of Terpinene in Hyptis species inhibited gastric lesions, reduced volume and acidity of the gastric juice and increased gastric wall mucus (Marcelo, Rafael \& Lucio 2015). Limonene, which is found in an appreciable amount in stem heartwood $(23.79 \%)$, stem bark (3.24\%) and root bark (13.93\%) EOs of C. inophyllum Linn, is known to have sedative and stimulative effects in Lippia alba (Vale et al. 2002; Viana, Vale \& Matos 2000). Consumption of diets containing fruits and vegetables rich in monoterpenes, such as limonene, is known to reduce the risk of developing cancer of the colon, mammary gland, liver, pancreas and lung. Limonene, which is known to possess high anticancer properties (Chistani et al. 2007; Marostica et al. 2009), is abundant in C. inophyllum Linn: leaf stalk $(25.40 \%)$, seed $(25.40 \%)$ and root bark (13.93\%) oils. The presence of phenylpropanoids, norisoprenoids and other non-ubiquitous compounds, such as $\beta$-alaskene, $\beta$-acoradiene and E-anethole, is a unique feature of oils from C. inophyllum Linn as shown in Table 2.

\section{2,2-diphenyl-1-picrylhydrazyl antioxidant activity of Calophyllum inophyllum Linn}

The percentage inhibition obtained for standard antioxidants (ascorbic acid and BHA) was relatively high for the concentration range used $(1.0 \mathrm{mg} / \mathrm{mL}-0.03125 \mathrm{mg} / \mathrm{mL})$. A maximum percentage inhibition of $92.68 \%$ and $91.67 \%$ was obtained at $1.0 \mathrm{mg} / \mathrm{mL}$ for ascorbic acid and BHA, respectively. The 10 oils (leaf, leaf stalk, flower, seed, pod, peel, stem wood, stem bark, root wood and root bark) exhibited concentration-dependent inhibition with reference to standard synthetic antioxidants used as a positive control. Percentage inhibitions of standards were in close range with pod EO, with inhibition efficiency of $78.32 \%$ at $1.0 \mathrm{mg} / \mathrm{mL}$ as indicated in Table 2. A graph of percentage DPPH inhibition versus concentration $(\mathrm{mg} / \mathrm{mL})$ of EOs was plotted from which the $\mathrm{IC}_{50}$ values were obtained for each oil using linear regression analysis in reference to standards (Figure 5). An inverse relationship exists between the percentage inhibition efficiency and the $\mathrm{IC}_{50}$ values. The higher the $\mathrm{IC}_{50}$ value, the lower the activity of the EOs and vice versa. The following $\mathrm{IC}_{50}$ values were obtained in the determination of $\mathrm{DPPH}$ inhibition: (leaf, $3.89 \mathrm{mg} / \mathrm{mL}$; leaf stalk, $4.17 \mathrm{mg} / \mathrm{mL}$; flower, $3.92 \mathrm{mg} / \mathrm{mL}$; seed, $3.49 \mathrm{mg} / \mathrm{mL}$; pod, $4.68 \mathrm{mg} / \mathrm{mL}$; peel, 3.64 $\mathrm{mg} / \mathrm{mL}$; stem wood, $3.93 \mathrm{mg} / \mathrm{mL}$; stem bark, $3.36 \mathrm{mg} / \mathrm{mL}$; root wood, $3.19 \mathrm{mg} / \mathrm{mL}$; and root bark, $3.87 \mathrm{mg} / \mathrm{mL}$ )

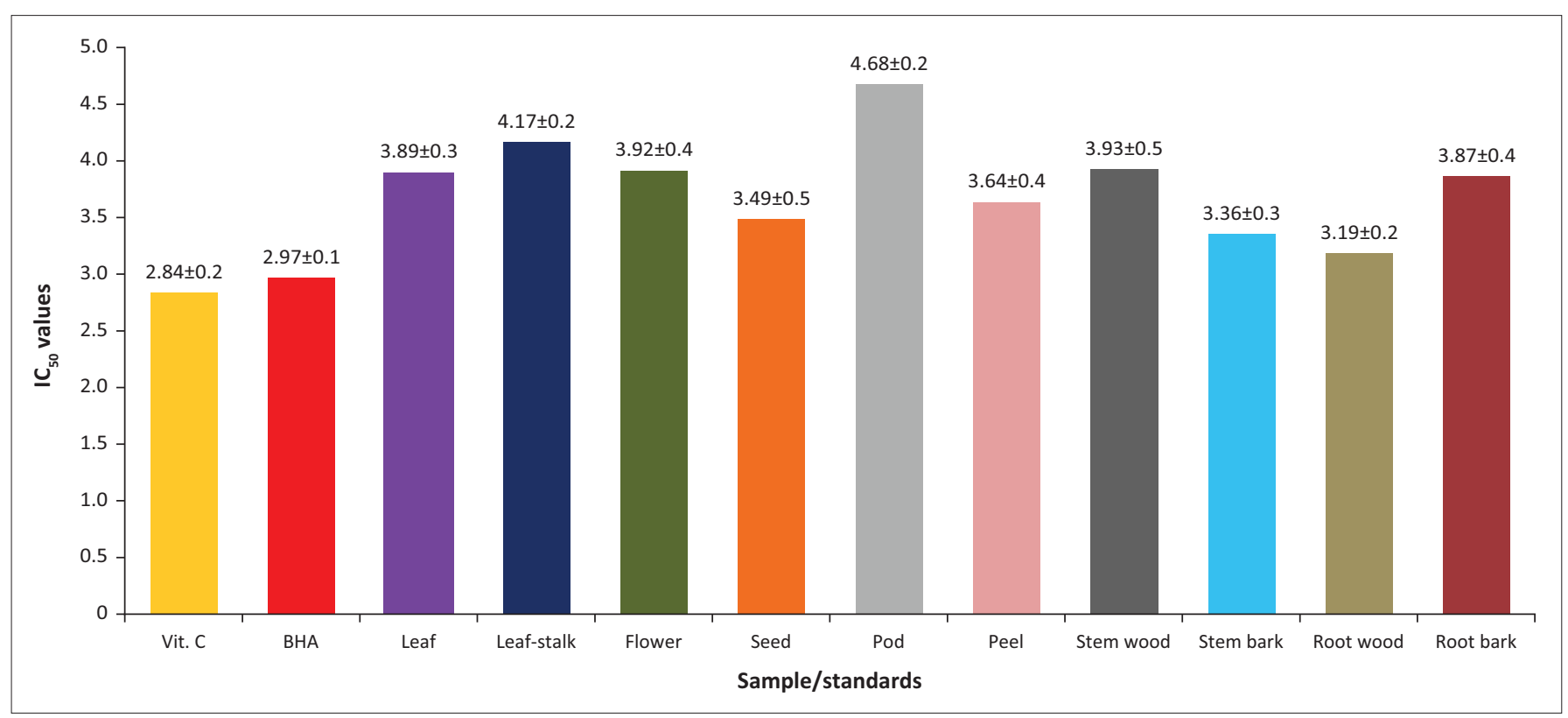

BHA, butylated hydroxyl anisole.

Note: All the results are mean \pm standard deviation (SD) where $n=3$. The half maximal inhibitory concentration (IC $\mathrm{C}_{50}$ ) was obtained in $\mathrm{mg} / \mathrm{mL}$ using non-linear regression analysis in Microsoft Excel. FIGURE 5: The half maximal inhibitory concentration values $(\mathrm{mg} / \mathrm{mL})$ for 2,2-diphenyl-1-picrylhydrazyl inhibition of Calophyllum inophyllum Linn. 
compared to standard antioxidants (vitamin C [2.84 mg/mL] and BHA [2.97]). The standard antioxidants with lowest $\mathrm{IC}_{50}$ values exhibited the highest antioxidant inhibition activity followed closely by the root wood $(3.19 \mathrm{mg} / \mathrm{mL})$. The least activity was expressed by pod oil $(4.68 \mathrm{mg} / \mathrm{mL})$. The high antioxidant activity of the root wood $\mathrm{EO}$ in comparison with standards must be because of the presence of some important bioactive phyto-constituents.

\section{Hydrogen peroxide scavenging activity of Calophyllum inophyllum Linn}

Optimum percentage inhibitions of $90.61 \%$ and $89.24 \%$ were obtained for ascorbic acid and BHA at $1.0 \mathrm{mg} / \mathrm{mL}$ and decreased slightly to $45.61 \%$ and $45.24 \%$ at $0.03125 \mathrm{mg} / \mathrm{mL}$, respectively. This trend indicates that the percentage inhibition of the standard used in this study is concentration dependent. The 10 oils (leaf, leaf stalk, flower, seed, pod, peel, stem wood, stem bark, root wood and root bark) exhibited concentration-dependent inhibition similar to standard synthetic antioxidants used. A graph of percentage inhibition versus concentration $(\mathrm{mg} / \mathrm{mL})$ of EOs was plotted from which the $\mathrm{IC}_{50}$ values were obtained for each oil using linear regression analysis in reference to the central standard. An inverse relationship exists between the percentage inhibition efficiency and the $\mathrm{IC}_{50}$ values (Figure 4). The higher the $\mathrm{IC}_{50}$ value, the lower the activity of the EOs and vice versa. The following $\mathrm{IC}_{50}$ values were obtained in the determination of $\alpha$-amylase inhibition: (leaf, $3.3 \mathrm{mg} / \mathrm{mL}$; leaf-stalk, $3.8 \mathrm{mg} / \mathrm{mL}$; flower, $3.18 \mathrm{mg} / \mathrm{mL}$; seed, $3.18 \mathrm{mg} / \mathrm{mL}$; pod, $4.32 \mathrm{mg} / \mathrm{mL}$; peel, $3.32 \mathrm{mg} / \mathrm{mL}$; stem wood, $3.56 \mathrm{mg} / \mathrm{mL}$; stem bark, $3.37 \mathrm{mg} / \mathrm{mL}$; root wood, $2.78 \mathrm{mg} / \mathrm{mL}$; and root bark, $3.63 \mathrm{mg} / \mathrm{mL}$ ) compared to standards (vitamin $\mathrm{C}[2.20 \mathrm{mg} / \mathrm{mL}]$ and BHA [2.92.36]).

Results obtained from the antioxidant assay are very consistent with the reported works in literature (Ajiboye et al. 2017; Bhaskara et al. 2015; Njenga \& Mugo 2020).

\section{Conclusion}

The antioxidant activity of characterised compounds of C. inophyllum Linn was presented for the first time and extends the knowledge in the broad range of biological activities and therapeutic prospects associated with this medicinal plant. Results from both DPPH and hydrogen peroxide assays established that C. inophyllum Linn EOs possess antioxidant and radical scavenging potential. However, the antioxidant properties were found to be slightly lower compared to standard antioxidants used (ascorbic acid and BHA). Despite having lower activity compared to standards, the antioxidant activity of $C$. inophyllum Linn was found to be significant for potential applications in pharmaceutical industries and could act as a potential alternative to more toxic synthetic antioxidants. Because of the toxic nature of EOs, further studies on the toxicity and other biological properties of the extract are needed prior to possible applications.

\section{Acknowledgements}

The authors are grateful to those who contributed immensely to the success of this study. They appreciate the effort of Mr. Donatus Esimehhuai of the Herbarium Unit of the Department of Botany, University of Ibadan, Nigeria, for plant authentication and assignment of voucher number.

\section{Competing interests}

The authors have declared that no competing interests exist.

\section{Authors' contributions}

D.O.M. designed the study, coordinated the collection and supervised all laboratory experiments. E.O.O. carried out the plant collection, essential oil extractions, the antioxidant activity of the plant and wrote the first draft of the manuscript. P.M.O. made substantial contribution by revising the manuscript critically. All authors read and approved the final manuscript.

\section{Funding information}

This research work was entirely funded by all the authors.

\section{Data availability statement}

Data sharing is not applicable to this article as no new data were created or analysed in this study.

\section{Disclaimer}

The views and opinions expressed in this article are those of the authors and do not necessarily reflect the official policy or position of any affiliated agency of the authors.

\section{References}

Ajiboye, C.O., Moronkola, D.O. \& Adesomoju, A.A., 2017, 'DPPH free radical scavenging activities of leaf, stem bark, root, flower and fruit of Blighia unijugata Baker (Sapindaceae) extracts', Journal of Chemical, Biological and Physical Sciences 7(4), 1190-1197. https://doi.org/10.24214/jcbps.B.7.4.119097

Barros, L., Cabrita, L., Boas, M.V., Carvalho, A.M. \& Ferreira, I.C.F.R., 2011, 'Chemical, biochemical and electrochemical assays to evaluate phytochemicals and antioxidant activity of wild plants', Food Chemistry 127(4), 1600-1608. https:// doi.org/10.1016/j.foodchem.2011.02.024

Bhaskara, R.K.V., Vidhya, T., Suji, T., Dhatchayani, R. \& Priya C.L., 2015, 'Evaluation of in-vitro antioxidant, antimicrobial activities and GC- MS analysis of Alternanthera bettizicikiana linn. leaf extracts', International Journal of Pharmacognosy and Phytochemical Research 7(6), 1072-1079.

Camilo, C.J., Alves-Nonato, C.F., Galvão-Rodrigues, F.F., Costa, W.D., Clemente, G.G., Sobreira-Macedo, M.A.C. et al., 2017, 'Acaricidal activity of essential oils: A review', Trends in Phytochemical Research 1(4), 183-198.

Chistani, M., Arrigo, M.D., Mandalari, G., Castelli, F. \& Sarpietro, M.G., 2007, 'Interaction of four monoterpenes contained in essential oils with model membranes: Implications for their antibacterial activity', Journal of Agriculture and Food Chemistry 55, 6300-6308. https://doi.org/10.1021/jf070094x

DeOliveira, T.M., DeCarvalho, R.B.F., daCosta, I.H.F., De Oliveira G.A.L., DeSouza, A.A., DeLima, S.G. et al., 2015, 'Evaluation of p-cymene, a natural antioxidant', Pharmaceutical Biology 53, 423-428. https://doi.org/10.3109/13880209.2014 923003

Dweck, A.C. \& Meadowst, T., 2002, 'Tamanu (Calophyllum inophyllum) - The African, Asian, Polynesian and Pacific Panacea', International Journal of Cosmetic Science 24, 1-8. https://doi.org/10.1046/j.1467-2494.2002.00160.x

Ebrahimzadeh, M.A. \& Bahramian, F., 2009, 'Antioxidant activity of Crataegus pentagina subsp. elbursis fruits extracts used in traditional medicine in Iran' Pakistan Journal of Biological Sciences 12(5), 413-419. https://doi.org/10.3923/ pjbs.2009.413.419 
Ganesan, K. \& Xu, B., 2017, 'Ethnobotanical studies on folkloric medicinal plants in Nainamalai, Namakkal District, Tamil Nadu, India', Trends in Phytochemical Research 1(3), 153-168.

Hassan, W., Gul, S., Noreen, H., ShahZ, M.I. \& Zaman, B., 2016, 'Chemical composition, essential oil characterization and antimicrobial activity of Carum copticum', Vitamins \& Minerals 5, 139. https://doi.org/10.4172/2376-1318.1000139

Kamalanathan, D., Srinivasan, R., Pratheeba, T., Yuvarajan, R. \& Natarajan, D., 2015 'Antioxidant activities of leaf extracts of Euphoria fusiformis Buch. -Ham. Ex D. Don (Euphorbiaceae)', Free Radicals and Antioxidants 5(2), 83-89. https://doi. org/10.5530/fra.2015.2.6

Marcelo, A.P., Rafael, M.M. \& Lucio, R.L.D., 2015, 'Gastroprotective effect of alphapinene and its correlation with antiulcerogenic activity of essential oils obtaine from Hyptis species', Pharmacognosy Magazine 11(41), 123-130. https://doi org/10.4103/0973-1296.149725

Marostica, M.R., Silva, T., Franchi, G.C., Nowill, A., Pastore, G.M. \& Hyslop, S., 2009 , 'Antioxidant potential of aroma compounds obtained by limonene biotransformation of orange essential oil', Food Chemistry 116, 8-12. https://doi.org/10.1016/j foodchem.2009.01.084

Mohammadhosseini, M., Akbarzadeh, A., Hashemi-Moghaddam, H., Mohammadi Nafchi, A., Mashayekhi, H.A. \& Aryanpour, A., 2016, 'Chemical composition of the Nafchi, A., Mashayekhi, H.A. \& Aryanpour, A., 2016, 'Chemical composition of the
essential oils from the aerial parts of Artemisia sieberi by using conventional essential oils from the aerial parts of Artemisia sieberi by using conventional
hydrodistillation and microwave assisted hydrodistillation: A comparative study', hydrodistillation and microwave assisted hydrodistillation: A comparative study',
Journal of Essential Oil Bearing Plants 19(1), 32-45. https://doi.org/10.1080/097 Journal of Essential Oil Be
2060X.2015.1119067

Njenga, P.K. \& Mugo, S.M., 2020, 'Chemical composition, antioxidant potential and antimicrobial activities of Ixora scheffleri subspecies keniensis essential oil' Journal of Medicinal Plants for Economic Development 4(1), 58. https://doi. org/10.4102/jomped.v4i1.58

Nunes, H.S. \& Miguel, M.G., 2017, 'Rosa damascena essential oils: A brief review about chemical composition and biological properties', Trends in Phytochemical Research 1(3), 111-128.
Pavunraj, M., Ramasubbu, G. \& Baskar, K., 2017, 'Leucas aspera (Willd.) L.: Antibacterial, antifungal and mosquitocidal activities', Trends in Phytochemical Research 1(3), 135-142.

Rattan, S.I., 2006, 'Theories of biological aging, genes, proteins and free radicals', Free Radical Research 40(12), 1230-1238. https://doi.org/10.1080/107157606 00911303

Saiket, S., Raja, C., Sridhar, C., Reddy, Y.S.R. \& Biplab, D., 2010, 'Free radicals, antioxidants diseases and phytomedicines: Current status and future prospect', Journal of Pharmaceutical Sciences 31(1), 91-100.

Serhat, K., Sait, C., Semra, T., Ökkes, Y. \& Ismail, T., 2012, 'Hydrogen peroxide radical scavenging and total antioxidant activity of hawthorn', Chemistry Journal 2(1), 9-12.

Uma, S.M., Murthy, P.N., Sudhir, K.S. \& Kanhu, C.S., 2012, 'Formulation and evaluation of herbal tablet containing methanolic extract of Calophyllum inophyllum', International Journal of Pharmacy 2(1), 181-186.

Ushio-Fukai, M. \& Nakamura, Y., 2008, 'Reactive oxygen species and angiogenesis: NADPH oxidase as target for cancer therapy', Cancer Letters 266(1), 37-52. https://doi.org/10.1016/j.canlet.2008.02.044

Vale, T.G., Furtado, E.C., Santos-Jr, J.G. \& Viana, G.S.B., 2002, 'Central effects of citral, myrcene and limonene constituents of essential oil chemotypes from Lippia alba (Mill.) N.E. Brown', Phytomedicine 9, 709-714. https://doi.org/10.1078/0944711 02321621304

Varsha, G., Uma, M.B., Ramasamy, M. \& Karunanithi, M., 2016, 'Effect of ethanolic extract of Calophyllum inophyllum leaves on oxidative stress complications in mouse model', Asian Journal of Pharmaceutical and Clinical Research 9(3), 250-252.

Viana, G.S.B., Vale, T.G. \& Matos, F.J.A., 2000, 'Anticonvulsant activity of essential oils and active principles from chemotypes of Lippia alba (Mill.) N.E. Brown', Biological and Pharmaceutical Bulletin 23, 1314-1317. https://doi.org/10.1248/bpb.23.1314

Yu, L.U. \& Young, W.J., 2016, 'Inhibitory effects of Calophyllum inophyllum extract on atopic dermatitis induced by DNCB in mouse', AJPCT 4(6), 165-173. 